\title{
Impact of Advertising on Branding in Small Towns and Villages of India
}

Chandan Maheshkar*, Vinod Sharma† Manohar Kapse ${ }^{\ddagger}$ and Akhilesh Tiwari§

\begin{abstract}
The consumer base for the Indian rural and semi-urban markets has been largely ignored by advertising practices. Specifically, the personal care products and their advertising practises are influenced by personality and individual perceptions. This paper reports the observations of the study conducted to identify the impact of advertising practices on branding of personal care products. It was found that advertising, suitability of content and advertisement media have no significant impact on the branding of personal care products in small towns and villages of India.
\end{abstract}

Keywords: Advertising, Branding Relationship, Personal Care Products

\section{Introduction}

Marketing of consumer products has been an area of interest to the entrepreneurs and academicians alike because of the magnitude

\footnotetext{
* Devi Ahilya University, Indore, MP, India; ch.maheshkar@gmail.com

† Christ Institute of Management, Delhi-NCR, India;

vinod.sharma@cimghaziabad.in

‡ CHRIST(Deemed to be University, Bangalore, India;

manohar.kapse@christuniversity.in

$\S$ Christ Institute of Management, Delhi-NCR, India;

akhilesh.tiwari@cimghaziabad.in
} 
and expansion rate of emerging markets such as BRIC nations (Craig \& Douglas, 2011). The scholarship on consumer products is a diverse area of research, primarily due to individual differences and economic deviations. India has $70 \%$ of the total $(1.3$ billion, 2015) population living in semi-urban and rural areas which are under various phases of development have minimal connectivity with urban areas or major cities.

The scholarship in branding suggests that the population in rural and semi-urban areas responds differently to the advertising messages and branding efforts of the companies. Although, the population in villages and semi-urban areas use many consumer products supplied by large corporations, the responses of these consumers to advertising messages and communication are different because of various reasons. India has her own unique societal and cultural characteristics (Italian Trade Commission, 2008). Through analysing unique ethnic characteristics and financial feasibility of Indian consumers, advertisers access this profitable target segment proficiently (Murlidharan \& Xue, 2014). Adopting region-specific factors, acknowledging regional languages, adopting different communication patterns, modifying types of promotion media and even presenting product attributes in specific ways are important parameters in making effective advertisements (Italian Trade Commission, 2008).

The effect of advertising can be seen on urban consumers who are exposed to the audiovisual media. There are many countries in the world where the sizable population is unexposed to print media and other media vehicles because of the low penetration of media in rural and semi-urban areas or because of illiteracy, wherein consumers cannot access the vocabulary of the advertisers.

Social bonding, mutual interdependence, and pastoral care are core value-based elements of the society in small towns and villages. Taking these elements into consideration is required to administer a business in small towns and villages of India. Geographic dispersion and the deficient distribution infrastructure demand a thorough rethinking of traditional approaches of marketing and the development of competent strategies to strike these markets of embryonic potential (Craig \& Douglas, 2011). 
It is a myth that customers of small towns and villages of India have no assessment capabilities because they use unbranded products. Advertising is a significant tool for brand building. Advertising, its content and selection of media to promote products are important to ignite the consumers' wants towards any product or service. However, advertisers have ignored the semi-urban and rural consumer markets which are continually growing. Therefore, this study aims to evaluate the impact of present advertisements, its content and advertising media on the branding of personal care products in small towns and villages of India.

For this study, one of the important challenges was to understand not only the requirements of the consumers of small towns and villages of India but also the surroundings in which they are living and consuming the products. The researchers had to understand that limited income does not necessarily imply a preference for lower prices, but rather, a more effective appraisal for value for money. To access the consumer markets of small towns and villages of India successfully necessitates a suitable marketing mechanism that would be relevant to the local community, their culture, literacy levels, and accessibility.

\subsection{Small Towns and Villages of India - At a Glance}

Nearly, 70\% of Indians (Majeed, 2014; The Hindu, 2011; India Census, 2011; Kumar, 2007) are inhabited in 6, 27, 000 villages and 8000 towns (Nielson Report, 2012) of India. 90\% of the rural population lives in villages with less than 2000 residents (Upadhyaya, 2010). Of these, more than two million people still live in absolute media darkness (Manwani, 2015; Kumar, 2007). Poor educational backgrounds coupled with multitude of languages (Baldridge, 1996) and dialects put most of these people beyond the reach of even conventional media planning. Scant information on rural lifestyle and consumption is a serious stumbling block to the planning and development of advertisement, its content and selection of suitable media. However, few studies have noted that human settlements in the rural and semi-urban regions have been elevated comparatively in terms of accessibility and reach in the last decades (Kundu \& Mohanan, 2009; Kumar, 2007). 
As reported by TPL (Technology Premier League, 2014), stout consumption of products in the financial system of the rural and semi-urban province is one of the key drivers for the FMCG business. FMCG companies create a considerably larger share of their total sales from outside the 100 or 150 prominent cities and towns of India (IBEF, 2010). Even with the delays, demand for products of wellness and appearance are continuously growing (IBEF, 2015; Rajaseker, 2015; AFS, 2013; Neilson, 2012; PWC, 2011; CII, 2010). Likewise, the responses from the rural regions for beauty, health and quality are continuously increasing. Thus, the demand for personal care products is growing across regions.

People from small towns and villages have started developing desires for personal care products, hi-tech products, automobiles, style frills, and other consumer durables. During the last five years, few corporations dealing with shopper merchandises have identified the market potential of rural and semi-urban regions and have decided to spend resources to understand and categorise the rural and semi-urban consumers according to their spending capacities, expectations, and lifestyles (Badugu \& Chauhan, 2011; Chaudhary, 2013).

\section{Review of Literature}

Advertising is a way to stimulate the intensity of consumer responses in terms of awareness, brand preferences, brand recognition, brand image, and quality expectations (Koslow et. al., 2006; Tellis, 2009; Luo \& Jong, 2012), and enables the organisations (Luo \& Jong, 2012) to share the advertisements across the targeted population. According to Freling, Crosno and Henard (2011), "there are benefits to having a favourable brand personality, such as enhanced brand attitudes and purchase intentions and higher levels of consumer trust and loyalty". Advertisements and brand elements (awareness, identity, image, positioning, personality and equity) play an important role in promoting the products' market performance which has significant implications for the changes in the consumers' mindsets. Solomon (2004) has expressed that when consumers like any advertisement and give their response for the product/service endorsed, it means, they are communicating their 
requirements, expectations, and attractions to the related organisation and/or industry.

The review of literature clarifies that consumers have considered advertisements as a reliable source of information (Rahman, 2012) which explains why advertisements have significant implications for brand perceptions and recognition (Brengman, Geuens \& Pelsmacker, 2001). It is difficult to build a brand only through advertising which follows the 'one size fits all' philosophy. In the words of Greg Stine (President of Polaris, Inc), "sometimes, the world of advertising and marketing is full of meaningless jargon, design-speak and techno-babble that seem to be created for no other purpose than to confuse the rest of us". Brand marketers increasingly seek to deploy more effective advertising strategies. As per Nielsen's (2012) survey report, chronic circulation of media messages may be impacting how well they resonate with their present and prospective buyers.

In recent years, Indian rural and semi-urban markets are being recognised as the growth of the financial system and have shown a substantial escalation in the purchasing power of the individuals of rural and semi-urban regions (Kotni, 2012). The rural and semiurban areas are using large amounts of urban manufactured items. In the rural and semi-urban settings, the unpredictability of income sources and low incomes together create separation in demands and the ability to purchase products compared to urban consumers (Craig \& Douglas, 2011). In contrast to the Indian urban society, which is now turning into a swift consumerist society, the rural and semi-urban consumers are always driven by their needs and income. Therefore, they are cost conscious and thrifty in their spending habits (Kumar, 2007). Since India is encountering a societal alteration (Kumar, 2007), availability, affordability, acceptability, and awareness of any product are the main challenges frequently faced by many competing organisations (Badugu \& Chauhan, 2011).

MART Knowledge Centre (2012) has reported that the sum of small towns and villages in India comprises a one trillion market with one billion consumers. The primary challenge for advertisers in the emerging markets is the fundamental understanding of the rural and semi-urban consumers who are evidently different from their 
urban counterparts. If advertisements can garner a sense of familiarity among consumers, then they can exhibit powerful persuasive power over the consumer's choices will (Whittler, 1989). Otherwise, consumers would feel disregarded and undermined and would not include themselves as an intended audience for the advertisement (Greco, 1989). So, the first target of an advertisement should be to stimulate the mindsets of consumers so that they can be convinced to attempt a trial or purchase the products.

The Indian market for personal care products is estimated at about US\$ 6 billion annually. Almost every Indian spends about 8-9 \% of his/her income on personal care products (TPL, 2014) and services. Based on urban and rural demographics, the Indian consumer markets can be categorised into multiple segments. The basic and essentials (e.g. shampoo, skin creams and so on) lead the personal care categories (Italian Trade Commission, 2008). Particularly, the skin care segment of the personal care market is in its initial stage in semi-urban and rural India. However, individuals are becoming more vigilant for their selections of personal grooming products because of rapid change in lifestyles, availability of large product alternatives (TPL, 2014), and status expectations. Rural India accounts for more than $40-45 \%$ consumption in major FMCG categories including personal care, fabric care, and hot beverages. The rural market has the approximate annual potential of USD 9 billion for personal care products (under FMCG). To target the right segment and cater to it in the markets of small towns and villages requires special attention and investigation.

Thus, the review of literature informs that while many studies have delved on the role of advertising in relation to building brand and rural FMCG market, the meticulous analysis to identify the impact of advertising, its content and associated media for branding are still needed. In the context of personal care products in small towns and villages of India, the review shows that the rural market is witnessing high growth and has more potential for FMCG including personal care segment. It is highlighted that small towns and villages are underestimated and misrepresented in the advertising of personal care product category. Therefore, quite mistakenly, it is hypothesised that there is no considerable impact of advertising, its content and chosen media on branding and its 
associated components for the purchase of personal care products in small towns and villages.

\section{Methodology}

An exploratory design of research was used to find the impact of advertising media on the branding of personal care products in small towns and villages of India. It is considered exploratory since it investigated the circumstances and documented the functioning and impacts of advertisement practices in rural and semi-urban regions. Responses were collected from 500 individuals by developing a structured questionnaire covering probable aspects of branding and advertising. In the present study, random convenient samples have been taken from different small towns and villages of India. The following criteria for the selection of towns and villages were followed:

Village: A rural setting with a small settlement of 500 to 2500 residents and a place where a large population is engaged in agricultural activities.

Town: A place with a municipality with a minimum population of 5,000 and a place where at least $75 \%$ of the male population are engaged in non-agricultural activities.

The questionnaire was tested over $5 \%$ of the total sample and suitable changes were made before implementing it. The questionnaire was tested extensively by contacting people from different backgrounds and localities. The villages and towns selected for the survey were also based on convenience. Thus, a survey was been conducted in villages and towns of the Indian state of Madhya Pradesh (Khandwa, Khargoan, Khar, Dhar, Kukshi, Sanawad, Borgaon, Pandhana, Manaver, Bhikangaon, Sehore and so on). Responses to each statement followed a fivepoint Likert's scale ranging from Strongly Agree to Strongly Disagree. Descriptive (mean, standard deviation and covariance) and inferential statistics (correlation analysis and regression analysis) have been used for analysis and testing of the hypotheses. 


\section{Analysis}

To test the inter-item consistency of variables, Cronbach Alpha reliability analysis was applied. Normally, it is acceptable when Cronbach's Alpha is $\geq 0.7$. In this study, all variables are more than 0.7 which confirms the instrument used in this study is reliable (Appendices, Table A).

The obtained chronology of branding elements has shown contradiction from the existing theoretical framework in the brand building process in small towns and villages of India for personal care products. Descriptive statistics have showed higher heterogeneity for brand awareness (i.e. $22.18 \%$ ) in small towns and villages. Advertising practices (18.34\%), advertisement content $(17.43 \%)$, and advertising media $(18.94 \%)$ showed heterogeneity from the statistical mean where advertising media used to promote personal care products in small towns and villages have consisted a higher heterogeneity among them (Appendices, Table B). These signify that consumers from small towns and villages are diverse than the elements considered for advertising and branding efforts.

The correlation analysis has shown that advertising and branding carried positive mediate correlation $(\mathrm{r}=0.48)$. This implicates that advertising is one of the affecting factors of personal care products' branding in small towns and villages of India. Brand personality, brand equity, brand awareness, brand identity, brand image and brand positioning have a positive but consecutively declining correlation with advertising. Theoretically, all these factors should have a moderately high correlation with advertising but in the case of small towns of India, it varies quantitatively (Table 1). This clearly shows that advertising has a deviated relationship with branding and its associated elements in the small town of India.

Table 1 Pearson's Correlation

\begin{tabular}{lccccccc}
\hline & $\begin{array}{c}\text { Brand } \\
\text { ing }\end{array}$ & $\begin{array}{c}\text { Brand } \\
\text { Aware } \\
\text { ness }\end{array}$ & $\begin{array}{c}\text { Brand } \\
\text { Iden } \\
\text { tity }\end{array}$ & $\begin{array}{c}\text { Brand } \\
\text { Image }\end{array}$ & $\begin{array}{c}\text { Brand } \\
\text { Position } \\
\text { ing }\end{array}$ & $\begin{array}{c}\text { Brand } \\
\text { Person } \\
\text { ality }\end{array}$ & $\begin{array}{c}\text { Brand } \\
\text { Equity }\end{array}$ \\
\hline Advertising & 0.48 & 0.32 & 0.31 & 0.24 & 0.20 & 0.36 & 0.32 \\
Ad Content & 0.21 & 0.29 & 0.22 & 0.21 & 0.20 & 0.33 & 0.21 \\
Ad Media & 0.16 & 0.46 & 0.24 & 0.06 & 0.25 & 0.07 & 0.22 \\
\hline
\end{tabular}


In the same way, advertisement content has shown a positive but poor correlation with brand personality, brand awareness, brand identity, brand image, branding, brand equity, and brand positioning in a declining manner (Table 1). From obtained values of correlation, it is apparent that the advertisement content affects brand personality to a high extent. Similarly, advertisement media has shown a positive correlation with brand awareness, brand positioning, brand identity, brand equity, branding, brand personality and brand image in a consecutively declining manner (Table 1). Brand awareness showed a fairly mediate correlation $(r=$ $0.47)$ with advertisement media. To evaluate the relationship of advertising with branding and its associated elements, a simple linear regression was estimated.

Table 2 Table 2: Regression Analysis and R Square Advertising v/s Branding of Personal Care Products in Small Towns of India

\begin{tabular}{|c|c|c|c|c|c|c|}
\hline \multirow[t]{2}{*}{ Model } & \multicolumn{2}{|c|}{$\begin{array}{l}\text { Unstandard } \\
\text { ized } \\
\text { Coefficients }\end{array}$} & \multirow{2}{*}{$\begin{array}{c}\begin{array}{c}\text { Standard } \\
\text { ized } \\
\text { Coefficients }\end{array} \\
\text { Beta }\end{array}$} & \multirow[t]{2}{*}{$\mathbf{t}$} & \multirow[t]{2}{*}{ Sig. } & \multirow{2}{*}{$\begin{array}{c}\mathbf{R} \\
\text { Square }\end{array}$} \\
\hline & $\beta$ & $\begin{array}{l}\text { Std. } \\
\text { Error }\end{array}$ & & & & \\
\hline 1 (Constant) & 8.40 & .86 & \multirow{3}{*}{.48} & 9.71 & .00 & \multirow{3}{*}{0.23} \\
\hline Advertising & $.55^{\mathrm{a}}$ & .04 & & 12.13 & .00 & \\
\hline 1 (Constant) & 11.20 & .94 & & 11.86 & .00 & \\
\hline Advertising & $.37 \mathrm{~b}$ & .05 & \multirow[t]{2}{*}{.38} & 7.45 & .00 & \multirow[t]{2}{*}{0.10} \\
\hline 1 (Constant) & 12.41 & .84 & & 14.75 & .00 & \\
\hline Advertising & $.32^{c}$ & .04 & \multirow[t]{2}{*}{.32} & 7.41 & .00 & \multirow[t]{2}{*}{0.10} \\
\hline 1 (Constant) & 13.94 & .92 & & 15.23 & .00 & \\
\hline Advertising & $.26^{\mathrm{d}}$ & .05 & \multirow[t]{2}{*}{.24} & 5.48 & .00 & \multirow[t]{2}{*}{0.06} \\
\hline 1 (Constant) & 11.83 & .79 & & 14.93 & .00 & \\
\hline Advertising & $.36^{\mathrm{e}}$ & .04 & \multirow[t]{2}{*}{.36} & 8.72 & .00 & \multirow[t]{2}{*}{0.13} \\
\hline 1 (Constant) & 15.33 & .78 & & 19.74 & .00 & \\
\hline Advertising & $.18^{f}$ & .04 & \multirow[t]{2}{*}{.20} & 4.57 & .00 & \multirow[t]{2}{*}{0.04} \\
\hline 1 (Constant) & 12.66 & .80 & & 15.77 & .00 & \\
\hline Advertising & $.32 \mathrm{~g}$ & .04 & .32 & 7.52 & .00 & 0.10 \\
\hline
\end{tabular}

a) Dependent Variable: Branding

b) Dependent Variable: Brand Awareness

c) Dependent Variable: Brand Identity

d) Dependent Variable: Brand Image

e) Dependent Variable: Brand Positioning

f) Dependent Variable: Brand Personality

g) Dependent Variable: Brand Equity 
predicted. The relationship between advertising and undertaken branding variables was found as shown in Fig 1 below:

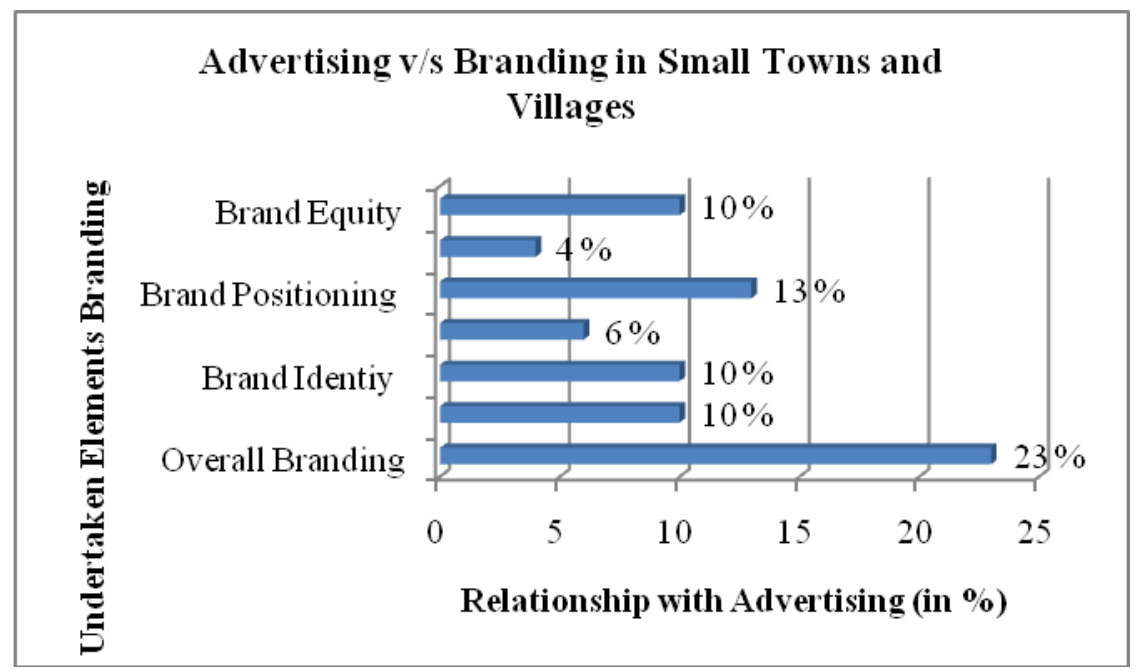

Fig 1 Advertising $\mathrm{v} / \mathrm{s}$ branding in small towns and villages

The following set of hypotheses was tested for the advertisements with respect to the branding of personal care products:

$\mathbf{H}_{01}$ : Advertising significantly affects the branding of personal care products in small towns and villages of India.

$\mathbf{H}_{01 \mathrm{~A}}$ : Advertising significantly affects the brand awareness of personal care products in small towns and villages of India

$\mathbf{H}_{01 \mathrm{~B}}$ : Advertising significantly affects the brand identity of personal care products in small towns and villages of India

$\mathbf{H}_{01 \mathrm{C}}$ : Advertising significantly affects the brand image of personal care products in small towns and villages of India.

$\mathbf{H}_{01 \mathrm{D}}$ : Advertising significantly affects the brand positioning of personal care products in small towns and villages of India.

$\mathbf{H}_{01 \mathrm{E}}$ : Advertising significantly affects the brand personality of personal care products in small towns and villages of India.

$\mathbf{H}_{01 \mathrm{~F}}$ : Advertising significantly affects the brand equity of personal care products in small towns and villages of India. 
Table 2 responds to the above-mentioned hypothesis.

1. The value of $t(9.71)$ is significant, thus the null hypothesis $\mathbf{H}_{01}$ is rejected i.e. there is no significant impact of advertising on the branding of personal care products in small towns and villages of India.

2. The value of $t(11.86)$ is significant, thus the null hypothesis $\mathrm{H}_{01 \mathrm{~A}}$ is rejected i.e. there is no significant effect of advertising on the brand awareness of personal care products in small towns and villages of India.

3. The value of $t(14.75)$ is significant, thus the null hypothesis $\mathbf{H}_{01 \mathrm{~B}}$ is rejected i.e. there is no significant effect of advertising on the brand identity of personal care products in small towns and villages of India.

4. The value of $t(15.23)$ is significant, thus the null hypothesis $\mathbf{H}_{01 \mathrm{C}}$ is rejected i.e. there is no significant effect of advertising on the brand image of personal care products in small towns of India and villages of India.

5. The value of $t$ (19.74) is significant, thus the null hypothesis $\mathbf{H}_{01 \mathrm{D}}$ is rejected i.e. there is no significant effect of advertising on the brand positioning of personal care products in small towns and villages of India.

6. The value of $t(14.93)$ is significant, thus the null hypothesis $\mathbf{H}_{01 \mathrm{E}}$ is rejected i.e. there is no significant effect of advertising on the brand personality of personal care products in small towns and villages of India.

7. The value of $t$ (15.77) is significant, thus the null hypothesis $\mathbf{H}_{01 \mathrm{~F}}$ is rejected i.e. there is no significant effect of advertising on the brand equity of personal care products in small towns and villages of India.

Therefore, based on the above results, the paper argues that the present advertising practices are not significantly influencing the branding of personal care products in small towns and villages of India. The study indicates that there is a need to rethink the advertising practices in small towns and villages and make changes accordingly. 
Table 3 Regression Analysis and R Square Advertisement Content $\mathrm{v} / \mathrm{s}$ Branding of Personal Care Products in Small Towns of India

\begin{tabular}{|c|c|c|c|c|c|c|}
\hline \multirow[t]{2}{*}{ Model } & \multicolumn{2}{|c|}{$\begin{array}{l}\text { Unstandardised } \\
\text { Coefficients }\end{array}$} & \multirow{2}{*}{$\begin{array}{c}\begin{array}{c}\text { Standardised } \\
\text { Coefficients }\end{array} \\
\text { Beta }\end{array}$} & \multirow[t]{2}{*}{$t$} & \multirow[t]{2}{*}{ Sig. } & \multirow{2}{*}{$\begin{array}{c}\mathbf{R} \\
\text { square }\end{array}$} \\
\hline & $\beta$ & Std. Error & & & & \\
\hline 1 (Constant) & 11.37 & 1.01 & & 13.80 & .00 & \\
\hline Ad Content & $.26^{\mathrm{a}}$ & .05 & .21 & 4.77 & .00 & 0.04 \\
\hline 1 (Constant) & 11.37 & 1.00 & & 11.37 & .00 & \\
\hline Ad Content & $.37 \mathrm{~b}$ & .05 & .29 & 6.86 & .00 & 0.09 \\
\hline 1 (Constant) & 13.94 & .91 & & 15.36 & .00 & \\
\hline Ad Content & $.25^{c}$ & .05 & .23 & 5.15 & .00 & 0.05 \\
\hline 1 (Constant) & 14.29 & .97 & & 14.77 & .00 & \\
\hline Ad Content & $.25^{\mathrm{d}}$ & .05 & .21 & 4.80 & .00 & 0.04 \\
\hline 1 (Constant) & 15.13 & .82 & & 18.55 & .00 & \\
\hline Ad Content & $.20^{\mathrm{e}}$ & .04 & .20 & 4.60 & .00 & 0.04 \\
\hline 1 (Constant) & 12.06 & .842 & & 14.33 & .00 & \\
\hline Ad Content & $.35^{\mathrm{f}}$ & .04 & .33 & 7.91 & .00 & 0.11 \\
\hline 1 (Constant) & 14.512 & .871 & & 16.67 & .00 & \\
\hline Ad Content & $.222 \mathrm{~g}$ & .046 & .209 & 4.77 & .00 & 0.04 \\
\hline
\end{tabular}

a) Dependent Variable: Branding

b) Dependent Variable: Brand Awareness

c) Dependent Variable: Brand Identity

d) Dependent Variable: Brand Image

e) Dependent Variable: Brand Positioning

f) Dependent Variable: Brand Personality

g) Dependent Variable: Brand Equity

Table 3 contains values of respective regression coefficients and $\mathrm{R}$ squares for the advertisement content through which concerned regression relation can be predicted. The relationship between advertisement content and associated branding variables found as shown in Fig 2 is presented below: 


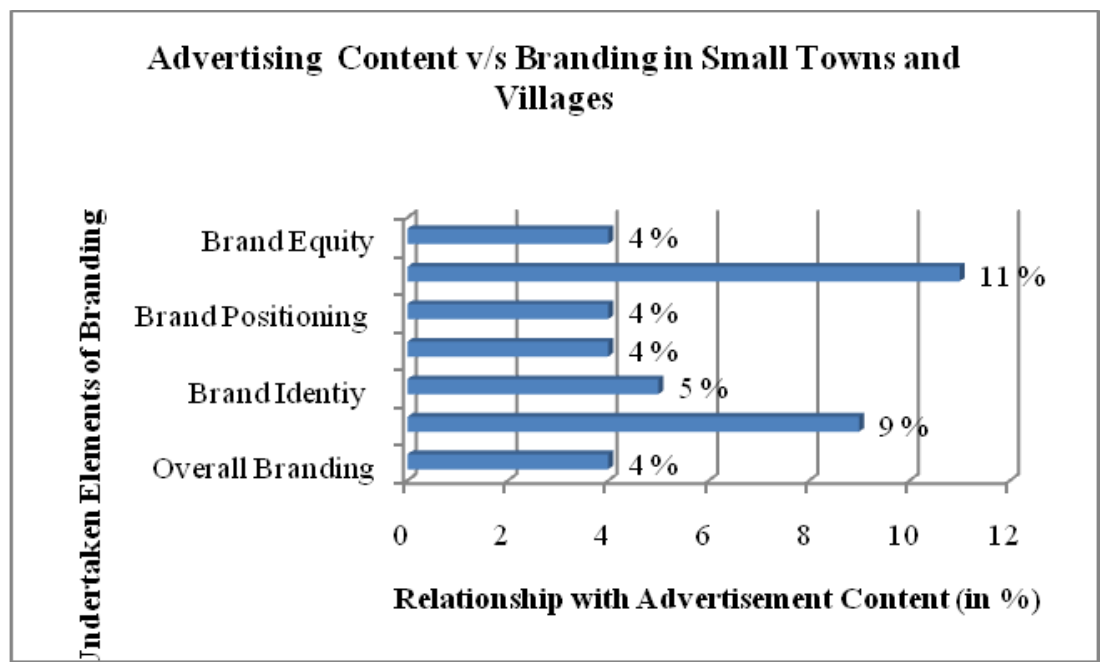

Fig 2 Impact of Advertisement Content on Branding of Personal Care Products in Small Towns and Villages of India

Hence, the following set of hypotheses tested for the advertisement content with respect to the branding of personal care products in small towns and villages of India.

$\mathbf{H}_{02}$ : Advertisement content significantly affects the branding of personal care products in small towns and villages of India.

$\mathbf{H}_{02 \mathrm{~A}}$ : Advertisement content significantly affects brand awareness of personal care products in small towns and villages of India.

$\mathbf{H}_{02 \mathrm{~B}}$ : Advertisement content significantly affects the brand identity of personal care products in small towns and villages of India.

$\mathbf{H}_{02 \mathrm{C}}$ : Advertisement content significantly affects brand image of personal care products in small towns and villages of India.

$\mathbf{H}_{02 \mathrm{D}}$ : Advertisement content significantly affects the brand positioning of personal care products in small towns and villages of India.

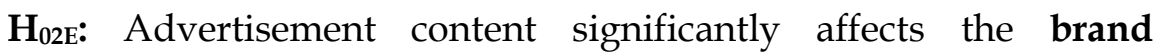
personality of personal care products in small towns and villages of India. 
$\mathbf{H}_{02 \mathrm{~F}}$ : Advertisement content significantly affects brand equity of personal care products in small towns and villages of India.

Table 3 provides justifications for the rejection of the above mentioned hypotheses.

1. The value of $t(13.80)$ is significant, thus the null hypothesis $\mathbf{H}_{02}$ is rejected i.e. there is no significant effect of advertisement content on the branding of personal care products in small towns of India.

2. The value of $t$ (11.37) is significant, thus the null hypothesis $\mathbf{H}_{02 \mathrm{~A}}$ is rejected i.e. there is no significant effect of advertisement content on brand awareness of personal care products in small towns of India.

3. The value of $t(15.36)$ is significant, thus the null hypothesis $\mathbf{H}_{02 \mathrm{~B}}$ is rejected i.e. there is no significant effect of advertisement content on brand identity of personal care products in small towns of India.

4. The value of $t(14.77)$ is significant, thus the null hypothesis $\mathbf{H}_{02} \mathrm{C}$ is rejected i.e. there is no significant effect of advertisement content on the brand image of personal care products in small towns of India.

5. The value of $t(18.55)$ is significant, thus the null hypothesis $\mathbf{H}_{02 \mathrm{D}}$ is rejected i.e. there is no significant effect of advertisement content on brand positioning of personal care products in small towns of India.

6. The value of $t(14.33)$ is significant, thus the null hypothesis $\mathrm{H}_{02 \mathrm{E}}$ is rejected i.e. there is no significant effect of advertisement content on the brand personality of personal care products in small towns of India.

7. The value of $t(16.67)$ is significant, thus the null hypothesis $\mathbf{H}_{02 \mathrm{~F}}$ is rejected i.e. there is no significant effect of advertisement content on the brand equity of personal care products in small towns of India.

Therefore, based on the above results, the present advertisement content is understood as having no significant influence on the branding of personal care products in small towns and villages of 
India. It is important that scholars address the advertisement content that connects with people and the environment in which they live. So, advertisers should revise the use of advertisement content and its quality for small towns and villages of India.

Table 4: Regression Analysis and R Square Advertisement Media $\mathrm{v} / \mathrm{s}$ Branding of Personal Care Products in Small Towns of India

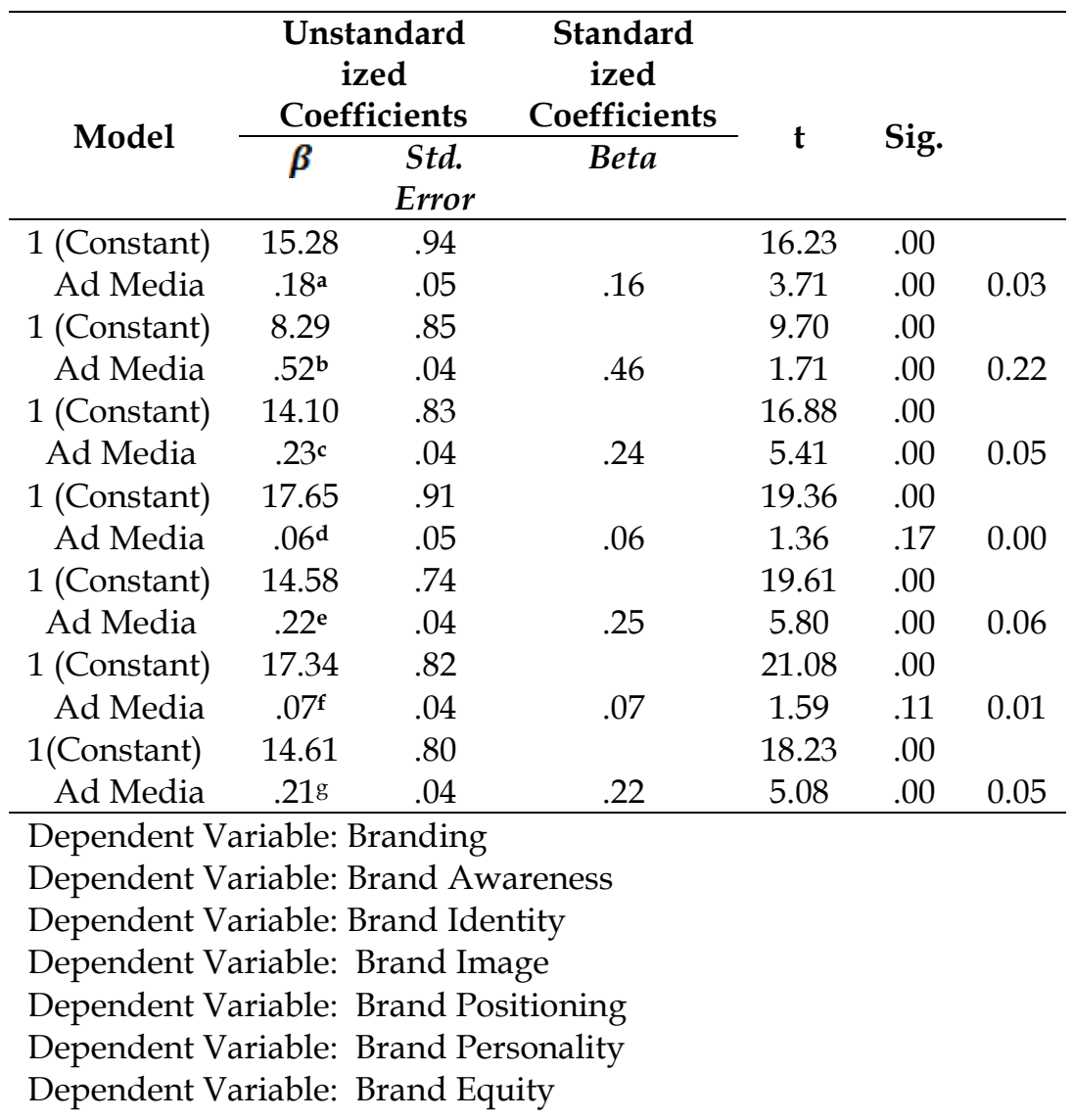

Table 4 contains values of respective regression coefficients and $\mathrm{R}$ squares for advertisement media through which concerned regression relation can be predicted. The relationship between advertisement media and branding variables undertaken is found as shown in $\mathrm{F}$ below: 


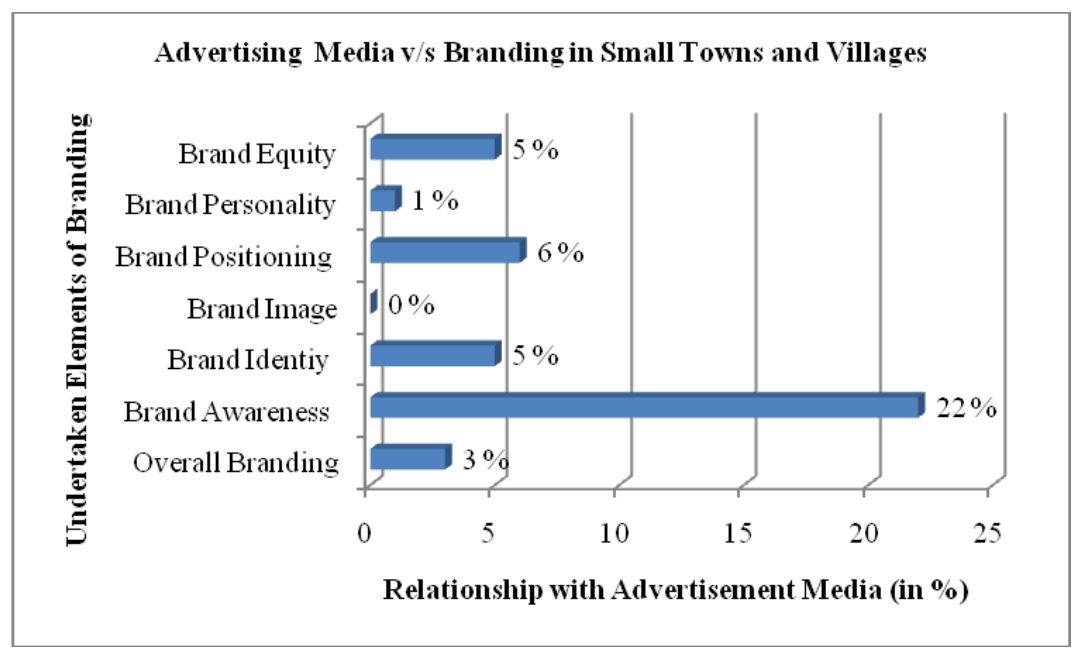

Fig 3 Impact of Advertisement Media on Branding of Personal Care Products in Small Towns \& Villages of India

Hence, the following set of hypotheses was tested for advertisement media with respect to the branding of personal care products in small towns and villages of India.

$\mathbf{H}_{03}$ : Advertisement media significantly affects the branding of personal care products in small towns and villages of India.

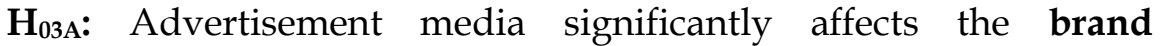
awareness of personal care products in small towns and villages of India.

$\mathbf{H}_{03 \mathrm{~B}}$ : Advertisement media significantly affects the brand identity of personal care products in small towns and villages of India.

$\mathbf{H}_{03 \mathrm{C}}$ : Advertisement media significantly affects brand image of personal care products in small towns and villages of India.

$\mathbf{H}_{03 \mathrm{D}}$ : Advertisement media significantly affects the brand positioning of personal care products in small towns and villages of India.

$\mathbf{H}_{03 \mathrm{E}}$ : Advertisement media significantly affects the brand personality of personal care products in small towns and villages of India. 
$\mathbf{H}_{03 \mathrm{~F}}$ : Advertisement media significantly affects brand equity of personal care products in small towns and villages of India.

The following can be concluded from Table 4 .

1. The value of $t(16.23)$ is significant, thus the null hypothesis $\mathbf{H}_{03}$ is rejected i.e. there is no significant effect of advertisement media on the branding of personal care products in small towns of India.

2. The value of $t$ (9.70) is significant, thus the null hypothesis $\mathbf{H}_{03 \mathrm{~A}}$ is rejected i.e. there is no significant effect of advertisement media on the brand awareness of personal care products in small towns of India.

3. The value of $t(16.88)$ is significant, thus the null hypothesis $\mathbf{H}_{03 \mathrm{~B}}$ is rejected i.e. there is no significant effect of advertisement media on the brand identity of personal care products in small towns of India.

4. The value of $t$ (19.36) is significant, thus the null hypothesis $\mathbf{H}_{03 \mathrm{C}}$ is rejected i.e. there is no significant effect of advertisement media on the brand image of personal care products in the small towns of India.

5. The value of $t$ (19.61) is significant, thus the null hypothesis $\mathbf{H}_{03 \mathrm{D}}$ is rejected i.e. there is no significant effect of advertisement media on brand positioning of personal care products in small towns of India.

6. The value of $t(21.08)$ is significant, thus the null hypothesis $\mathbf{H}_{03 \mathrm{E}}$ is rejected i.e. there is no significant effect of advertisement media on the brand personality of personal care products in small towns of India.

7. The value of $t(18.23)$ is significant, thus the null hypothesis $\mathbf{H}_{03 \mathrm{~F}}$ is rejected i.e. there is no significant effect of advertisement media on the brand equity of personal care products in small towns of India.

Therefore, based on the above results, the paper asserts that the present advertisement media do not significantly affect the branding of personal care products in small towns and villages of India. The results indicate that there is a need to revise the 
selection of appropriate advertisement media and its quality in small towns and villages.

To examine if the regression achieved its purpose of explaining variation or not, residuals of regression were checked. Ideally, all residuals should be small and unstructured. In this study, regression residuals are normally distributed. This implies that regression analysis has successfully explained the essential parts of a variation of dependent variables.

\section{Findings}

India boasts of a diverse market because of its differing characteristics chequered with diversity in age, income, and urbanrural demography (Italian Trade Commission, 2008). There are many distinct aspects of businesses in small towns and villages, giving insights and opportunities for hosting a gigantic consumer market, almost in all businesses where community, relationships and people matter (Pulver \& Vonage, 2012). The followings are the major findings of this study.

1. The results have notified that traditional theory of advertising and processes of brand building are not holistically universal; these vary by demographic and societal constraints to which customers belong. In the case of Indian towns and villages, consumers heterogeneously responded towards the advertising practices and brand building for personal care products.

2. Advertising is a significant tool to create brand awareness. In small towns and villages, brand awareness of personal care products has a higher heterogeneity among people. This heterogeneity means segments are fragmented. Hence, common messages for the urban and rural audience will not affect the targeted rural audience in an expected manner.

3. Because of the ignorance of rural settings in advertising practices, brand awareness, brand identity, brand image, brand positioning, brand personality, and brand equity have demonstrated poor positive correlation (Table 1) with advertising in a declining manner. It appears that most of 
the FMCG product advertisements have been created to target urban population only.

4. Advertisement content and advertisement media are two important aspects of effective advertising practices. Advertisement content has an important role in making people aware and building a brand personality for personal care products in small towns and villages of India. Selecting advertising media appropriate to small towns and villages drastically affect brand awareness of personal care products. Hence, the specific language, expression and context are required to be created for small towns and villages (rural and semi-urban).

5. Advertisement content has shown a declining poor positive correlation (Table 1) with brand awareness, brand identity, brand image, brand positioning, brand personality and brand equity respectively. The reason is the use of out-ofcontext content. Effective content gets attention, holds interest and arouses desires. Practically, the advertisement must consider content, audience, presentation and the means of expression. Thus, advertisements should consider content quality, the language to be used, and the context it is set in.

6. Selection of appropriate advertisement media is important to achieve the objectives of advertising and branding. The nature of products, target market, and their requirements, media availability and acceptability as being reliable, and advertisement budget are factors that affect the selection of appropriate media. The results indicated consecutively declining, poor positive correlation (Table 1) of advertising media with brand awareness, brand identity, brand image, brand positioning, brand personality, and brand equity respectively. This indicates that specific attention is required to be given for the semi-urban and rural audience. So, the advertisers should choose suitable advertising media relevant to the demographics of small towns and villages of India. 
7. The domesticity of advertisements is an important strategy of product branding in small towns and villages. The similarities between consumer and elements of advertisements create the highest persuasion. Otherwise, consumers would feel ignored and wouldn't be considering themselves for an intended target of the advertisement (Greco, 1989).

8. Since diversity is an integral part of the communal and cultural composition in India, it is very difficult to include all types of cultural and communal settings in a single advertisement. Particularly in the small towns and villages of India, marketing poses several challenges, apart from the geographical distance and remoteness of various places. Considering rural and semi-urban market can generate higher revenues for personal care products as well as others, if companies target right and cater right in their marketing and advertising practices. Language, aesthetic style, and associated themes are three principal components of rural settings and these should be included in marketing and advertising practices.

9. During the study, it was also found that people of towns and villages use the word 'brand' (and 'branded') interchangeably for the 'Product of High Quality', 'Company's Original Product', 'Costly Products' and 'Product of Status'. It is a general belief among people that 'branded' implies products of high cost with high quality. Most customers in rural settings are cost sensitive.

Therefore, advertising practices, advertisement content and advertisement media have no significant impact on the branding of personal care products in small towns and villages of India. The impact of advertising practices on the branding of personal care products in small towns and villages is much less than expected. This confirms that rural consumers of FMCG have been largely ignored by advertisers (Murlidharan \& Xue, 2014). This happens due to the difference in perceptions and decision making of consumers from small towns and villages. This difference is significant for making advertising strategies, framing suitable content and media, deciding the budget, and its probable impacts 
on sales. This does not undermine the impact of advertising on branding or any traditional theoretical mix of advertising or branding. It signifies the need of value proposition in advertising and branding practices required for attracting the consumers of small towns and villages since small towns and villages contribute a significant portion to the country's economy. Through a consideration of the facts, sales of personal care products and other consumer durables can be boosted in small towns and villages of India. This is a promising situation for advertising practitioners and academicians to fabricate the contextual theories and practices which cover the possible customer groups, and their environment in which they live and consume.

\section{Discussion}

The study signifies the role of perceptions of the rural and semiurban consumers and their feelings about advertisements. Rural consumers react to advertising content differently from urban consumers. Advertising contributes more to creating brand awareness in rural areas than in urban areas where it may contribute to creating associations and brand personality. It may contribute to brand building processes in a different manner. In rural areas mostly, products are bought out of their urgency of needs and not for social acceptance which may be a case for urban consumers.

For a large number of advertisements, rural consumers are not able to connect themselves and hence there is a large gap between the information given and information processed. This does not apply to urban consumers. This is an important reason why advertisements do not affect the creation of brand for rural consumers. There is a need to study the impact of content, style, media and language of advertisements on the rural consumers in detail with the larger sample of rural consumers to measure its relationship with the creation of brands in rural areas.

This difference in the demographics is more evident in countries like India because over $65 \%$ of the population (around 800 million people) live in rural and semi-urban areas and the consumption rate of this portion of the population is changing fast. To be more 
effective, the advertisers must study, analyse and interpret the needs, impacts, and expectations of the rural population.

\section{Conclusion}

Advertising theories have proved that the creation of a brand is the result of sustained messaging from the creators of brands to the consumers. This continuous communication through different media platforms including advertising generates all aspects of branding right from creating brand awareness to creating brand associations. It is assumed that the impact of advertising on branding is the same in metros and in small towns. The research indicates an important gap between advertising theory and practices in small towns and villages, particularly pertaining to personal care products. There is a wide and significant variation in advertising practices and the use of information for promoting personal care products. The study has shown that advertisers and manufacturers of personal care products in small towns and villages of India have used the strategy 'one size fits all' and have used the same advertising and commutation messages for every audience whether it is urban or rural.

If an advertisement shows similarities between consumers and advertising elements, the persuasion is at its highest (Whittler, 1989). Otherwise, the impact of adverting will not be as expected. The content used in advertisements is not so influencing to an audience of small towns and villages in India. It is also identified that the advertisement media plays an important role in promoting the brand but there is a need to select appropriate advertisement media and its quality in case of small towns and villages. The major influences of advertising on the branding of personal care products have not been adequately covered all types of consumers. Therefore, the results indicated a need to rethink consciously in the possible dimensions about advertising practice in small towns and villages and make the necessary changes accordingly. 


\section{References}

AFS. (2013). Research Report: Indian FMCG Industry. http:// reports.dionglobal.in/Actionfinadmin/Reports/FDR0108201343.pdf Accessed on October 27, 2015.

Agres, S. J., \& Dubritsky, A. M. (1996). Changing needs for brands. Journal of Advertising Research, 36(1), 21-30.

Badugu, D., \& Chauhan, S. S. (2011). Understanding the Indian rural market potential. Zenith International Journal of Multidisciplinary Research, 1(6), 68-82.

Baldridge, J. (1996). Reconciling linguistic diversity: the history and the future of language policy in India. University of Toledo. Retrieved from http://www.ling.upenn.edu/ jason2/papers/natlang.htm Accessed Oct. 27, 2015.

Brengman, M., Geuens, M., \& Pelsmacker, P. D. (2001). The impact of consumer characteristics and campaign related factors on brand confusion in print advertising. Journal of Marketing Communications, $7(4), 231-243$.

Census of India. (2011). Provisional population totals urban agglomerations and cities. Retrieved from http://censusindia.gov.in/2011-proveresults/paper2/data_files/India2/1.\%20Data\%20Highlight.pdf Accessed February 2, 2015.

Chaudhary, S. V. (2013). Corporate initiatives and innovations in rural market of India. Retrieved from http://www.indianmba.com/ Faculty_Column/ FC1520/fc1520.html (Accessed December 05, 2015).

CII. (2010). FMCG Roadmap to 2020. Report prepared by Booz \& Company Inc. for the Confederation of Indian Industry (CII). http:/ / www.strategyand.pwc.com/media/file/CII_FMCGRoadmap-to-2020.pdf. Accessed on October 28, 2015.

Craig, C. S., \& Douglas, S. P. (2011). Empowering rural consumers in emerging markets. International Journal of Emerging Markets, 6(4), 382393.

Freling, T. H., Crosno, J. L., \& Henard, D. H. (2011). Brand personality appeal: conceptualization and empirical validation. Journal of the Academy of Marketing Science, 39, 392-406.

Greco, A. J. (1989). Representation of the Elderly in Advertising: Crisis or Inconsequence. Journal of Con-sumer Marketing, 6(1), 37-44.

IBEF. (2010). Fast Moving Consumer Goods (FMCG). Report by India Brand Equity Foundation. Retrieved from 
http://www.ibef.org/download/FMCG-August-2015.pdf. Accessed on October 28, 2015.

IBEF. (2015). Fast Moving Consumer Goods. Report by India Brand Equity Foundation. http://www.ibef.org/download/FMCG-August2015.pdf. Accessed on October 28, 2015.

Italian Trade Commission. (2008). Market survey on India's cosmetics and personal care sector. New Delhi: Trade Promotion Section of the Italian Embassy. Retrieved on http://italiaindia.com/ images/ uploads/ pdf/cosmetics-personal-care\%20-2008.pdf. Accessed on March 17, 2015.

Koslow, S., Sasser, S., \& Riordan, E. (2006). Do marketers get the advertising they need or the advertising they deserve? Journal of Advertising, 35(3), 81-101.

Kotni, V. V., \& Prasad, D. (2012). Prospects and problems of Indian rural markets. Zenith International Journal of Business Economics $\mathcal{E}$ Management Research, 2(3), 200-213.

Kumar, L. R. (2007). Role of marketing communication in enhancement of quality of life in rural India. Intercultural Communication Studies, 16(1), 46-55.

Kundu, A., \& Mohanan, P. C. (2009). Employment and inequality outcomes in India. In Joint Seminar on Employment and Inequality organized by the Employment, Labour and Social Affairs Directorate and Development Centre, Paris, 8, 1-43.

Luo, X., \& De Jong, P. J. (2012). Does advertising spending really work? The intermediate role of analysis in the impact of advertising on firm value. Journal of the Academy of Marketing Science, 40, 605-624.

Majeed, S. (2014). Brand awareness in rural area: A case study of fast moving consumer goods in Pulwama district of J\&K state. International Journal of Business and Management Invention, 3(5), 50-53.

Manwani, H. (2015). Serving Many Indias. https://www.hul.co.in/ Images/harish-Manwani-AGM-speech-2015-serving-many-indias_ tcm1255-463778_1_en.pdf. Accessed on October 24, 2015.

MART. (2012). Rural growth story. MART knowledge center. Retrieved from http://www.martrural.com/docs/kn-series/MART-RuralGrowth-Story-2012.pdf.

Muralidharan, S. \& Xue, F. (2014). Influence of TV endorser types on advertising attitudes and purchase intention among Indian rural women: an exploratory study. Asian Journal of Communication. DOI: 10.1080/01292986.2014.944923

Nielson Report. (2012). Emerging consumer demand: rise of the small town Indian. Retrieved from http://www.nielsen.com/ 
content/dam/ corporate/ india/ reports/ 2012/ Emerging \%20 Consumer \%20Demand $\%$ 20\%E2\%80\%93\%20Rise \% 20of \%20the \% 20Sma 11\%20Town\%20Indian.pdf. Accessed on March 21, 2015.

Nielson Report. (2012). Global trust in advertising and brand messages. The Nielson Company. Retrieved from www.nielsen.com on March 21, 2015.

Pulver, J., \& Vonage. (2012). Why learn from small towns? What business people are saying. In B. J.Moltz \& B. McCray (Eds.), Small town rules: how big brands and small businesses can prosper in a connected economy. Que Publishing.

PWC. (2011). Riding the growth wave-wellness. Retrieved from https:/ / www.pwc.in/ assets/pdfs/publications-2011/wellness-report-15sept.pdf.

Rahman, M. N. (2012). Impact of advertisement: an empirical study of FMCG products in KSA. Asian Journal of Multidimensional Research, $1(4), 1-15$.

Rajasekar. (2015). FMCG-India. https://www.linkedin.com/pulse/fmcgindia-kumar-rajasekar. Accessed on October 28, 2015.

Solomon, M. (2004). Consumer Behavior: Buying, Having and, Being (6th Ed.). FT Prentice-Hall Upper Saddle River.

Stine, G. (2015). The nine principles of branding. Polaris, Inc. Retrieved from http://www.polaris-inc.com/ assets/ pdfs/ 9_principles_of_branding.pdf.

Technology Premier League. (2014). Website primary content. Retrieved from http://www.tpl2014.com/.

Tellis, G. (2009). Generalizations about advertising effectiveness in markets. Journal of Advertising Research, 49(2), 240-245.

The Hindu. (2011). About 70 per cent of Indians Lives in rural areas: Census report. http://www.thehindu.com/news/national/about-70per-cent-indians-live-in-rural-areas-census-report/article2230211.ece (Accessed May 10, 2015).

Upadhyaya, M. (2012). Marketing in rural India: the innovative selling mantra. Journal of Research in Commerce \& Management, 1(10), 77- 84. Appendices

Whittler, T. E. (1989). "Viewers' Pro- cessing of Actor's Race and Message Claims in Advertising Stimuli." Psychology and Marketing, 6(Winter), 287-309. 


\section{Appendices}

Table A Reliability Statistics

\begin{tabular}{lcc}
\hline Sr. No. & Cronbach's Alpha & Number of Variables \\
\hline 1 & .76 & 8 \\
2 & .74 & 8 \\
3 & .74 & 8 \\
\hline
\end{tabular}

Table B: Descriptive Statistics

\begin{tabular}{llllll}
\hline \multirow{2}{*}{ Variable } & \multicolumn{2}{c}{ Mean } & \multicolumn{3}{c}{ Co-variance } \\
\cline { 2 - 4 } (In \%) & N \\
\hline Advertising & Statistic & Std. Error & Std. Deviation & 18.34 & 500 \\
Ad Content & 18.90 & .155 & 3.47 & 17.43 & 500 \\
Ad Media & 18.46 & .144 & 3.22 & 18.94 & 500 \\
Branding Practices & 18.98 & .161 & 3.59 & 21.18 & 500 \\
Brand Awareness & 18.12 & .177 & 3.96 & 22.12 & 500 \\
Brand Identity & 18.54 & .160 & 3.57 & 19.25 & 500 \\
Brand Image & 18.87 & .170 & 3.79 & 20.10 & 500 \\
Brand Personality & 18.62 & .153 & 3.42 & 18.38 & 500 \\
Brand Positioning & 18.82 & .143 & 3.19 & 16.95 & 500 \\
Brand Equity & 18.61 & .153 & 3.41 & 18.34 & 500 \\
\hline
\end{tabular}

